\title{
EL SEÑORÍO TEMPORAL DE LOS OBISPOS DE SEGOVIA EN LA EDAD MEDIA ${ }^{1}$
}

\author{
BONIFACIO BARTOLOMÉ HERRERO
} Universidad Complutense de Madrid

\section{SUMARIO}

Introducción.- 1. Siglo XII. Período fundacional.- 2. Siglos XIII-XIV-XV. Evolución y conflictividad.- 3. Siglo XVI. Desmembración del señorío.- 4. Turégano y Mojados, pervivencias señoriales.- 5. Relación de lugares de señorío episcopal y capitular.

\section{INTRODUCCIÓN}

El estudio de los señoríos es uno de los temas historiográficos con más arraigo en el campo de la historia medieval. Dentro del mismo, la mayoría de los trabajos han estado dedicados a los señoríos nobiliarios,

\footnotetext{
'Abreviaturas utilizadas:

ACS: Archivo Catedralicio de Segovia.

ADS: Archivo Diocesano de Segovia.

Colmenares: D. de Colmenares, Historia de la insigne ciudad de Segovia y conpendio de las historias de Castilla, Segovia, 1637. (Reed., 2 vols., Segovia, 1969-70. Ed. por la que aquí se cita).

Cuéllar: A. Ubieto ArTeta, Colección diplomática de Cuéllar, Segovia, 1961.

RIAZA: A. UBIETo ARTETA, Colección diplomática de Riaza (1258-1457), Segovia, 1959.

SANZ: H. SANZ Y SANZ, Catálogo de la colección diplomática medieval, 1115-1500, del archivo catedralicio de Segovia, Segovia, 1988.

SEPÚlVEDA: E. SÁEZ, Colección diplomática de Sepúlveda I (1076-1454), Segovia, 1956.

VILlAR: L.M. VILlAR GARCíA, Documentación medieval de la catedral de Segovia (11151300), Salamanca, 1990.
} 
quedando los eclesiásticos en un segundo plano ${ }^{2}$. Afortunadamente, esta situación está siendo superada poco a poco, y en el caso concreto de los señoríos se ha podido constatar, descontando las lógicas particularidades de unas y otras, la existencia de más coincidencias que divergencias entre las posesiones nobiliarias y las eclesiásticas. Por lo tanto, los señoríos eclesiásticos no constituían una excepción institucional ni económica, sino que estaban plenamente integrados en el contexto histórico en que nacieron y se desarrollaron. El caso segoviano tampoco constituye ninguna excepción, es más, su evolución se ajusta casi perfectamente al esquema propuesto por Salvador de Moxó para los señoríos eclesiásticos ${ }^{3}$.

Los trabajos que hasta el momento se han ocupado de los obispos de Segovia como señores de vasallos se han limitado en general a determinadas coordenadas cronológicas ${ }^{4}$ o geográficas ${ }^{5}$, siendo la publicación de fuentes sobre este tema practicamente inexistente ${ }^{6}$. El señorío capitular, originado

\footnotetext{
${ }^{2}$ Se puede citar aquí una obra clásica como la de A. LÓPEZ PELÁEZ, El señorío temporal de los obispos de Lugo, 2 vols., La Coruña, 1897; un artículo general y todavía de interés como el de M. PÉREZ VILlamil, El señorio temporal de los obispos de España en la Edad Media, "Boletín de la Real Academia de la Historia", LXVIII (1916), pp. 361-390; y diversos trabajos de S. de Moxó, Las desamortizaciones eclesiásticas del siglo XVI, "Anuario de Historia del Derecho Español", XXXI (1961), pp. 327-361; La incorporación de señoríos eclesiásticos, "Hispania", XXIII (1963), pp. 219-254; y la voz Señoríos eclesiásticos en el "Diccionario de Historia Eclesiástica de España", suplemento I, Madrid, 1987, pp. 676-684.

${ }^{3}$ S. de Moxó, Señortos eclesiásticos, (citado en nota 1), pp. 677-679.

${ }^{4}$ Colmenares incluyó numerosas noticias relativas a este señorío; J. GoNZÁLEZ, La extremadura castellana al mediar el siglo XIII, "Hispania", 127 (1974), pp. 385-387, se centra en la formación del señorío episcopal; M. BARRIO GOZALO, Estudio socio-económico de la iglesia de Segovia en el siglo XVIII, Segovia, 1982, realiza una visión de interés sobre la fundación y los aspectos económicos del señorío en sus momentos finales entre las pp. 200-210; G. MARTÍNEZ DíEZ, Las comunidades de Villa y Tierra de la Extremadura Castellana, Madrid, 1983, pp. 511-514, trata de la "Episcopalía de Segovia" en su período fundacional pero exclusivamente a través de datos tomados de Colmenares.

${ }^{5}$ E. Colorado y LaCA, El castillo de Turégano, "Estudios Segovianos", VIII (1956), pp. 54-76, que estudia la fortaleza, especialmente durante el episcopado de Juan Arias Dávila; J.A. RUIZ HERnANDO, Las fortalezas de Laguna de Contreras y de Turégano, "Estudios Segovianos", XXVII (1975), pp. 101-122, que estudia la arquitectura de los dos castillos de señorío episcopal; M.E. CONTRERAS JIMÉNEZ, Las fortalezas del obispo de Segovia: Turégano y Lagunillas, "Castillos de España", 95 (1988), pp. 59-66, que aporta documentación de los castillos durante los siglos XV y XVI; V. BORREGUERO VIRSEDA, El señorío episcopal de Turégano (Otras historias de Castilla), Segovia, 1991, que centra su trabajo en la villa de Turégano y aporta abundante documentación para la época moderna; A. de CEBALLOSESCALERA Y GILA, El régimen señorial en la provincia de Segovia (Señores y vasallos), Segovia, 1995, que estudia brevemente algunas de las villas de señorío episcopal y capitular.

${ }^{6} \mathrm{M}$. Quintanilla, Venta de las villas del cabildo, "Estudios Segovianos", VI (1954), pp. 336-338. Es la transcripción de la copia que Colmenares conservaba entre sus papeles del poder que el cabildo había otorgado a sus procuradores el 20 de octubre de 1536 para llevar a cabo
} 
a partir del episcopal, sí cuenta con un estudio general ${ }^{7}$. Por el contrario, el señorío monástico en la diócesis segoviana resulta hasta hoy un fenómeno prácticamente desconocido ${ }^{8}$.

El principal objetivo del presente artículo es el de ofrecer una visión global del señorío de los obispos de Segovia desde su formación, en los inicios del siglo XII, hasta su liquidación en el siglo XIX, haciendo especial hincapié en su desarrollo durante la etapa medieval.

\section{Siglo XII. PERÍODO FUNDACIONAL}

La constitución del señorío temporal de los obispos de Segovia se inició antes de 1122, con la donación del concejo de la ciudad al obispo de "hereditatem illam de Sotis Albis", esto es, Sotosalbos ${ }^{9}$. En 1123 la reina doña Urraca hacía donación de Turégano, Caballar y Collado Hermoso ${ }^{10}$. Alfonso VII entregó a los prelados Bavilafunt, Aguilafuente, y Bovadela, Bobadilla, en 1124 recibiendo a cambio la villa de Elesches, Illescas ${ }^{11}$. Antes de 1130 el propio monarca donaba al obispo "ecclesiam beati Petri de

la venta de las tres villas cuyo señorío detentaba. Diversas colecciones diplomáticas, como las de Cuéllar, Riaza o Sepúlveda, o la de la catedral de Segovia, incluyen numerosa documentación referente al señorío episcopal y capitular en la época medieval.

${ }^{7}$ M. SANTAMARÍA LANChO, Lugares de señorio del cabildo catedralicio de Segovia: notas para el estudio de la crisis del sistema feudal en la Castilla del siglo XV, en "El pasado histórico de Castilla y León", vol. I, Burgos, 1983, pp. 441-461.

${ }^{8} \mathrm{La}$ mejor síntesis del mismo es la de M. BARRIo Gozalo, op. cit., pp. 615-621. También incluyen algunas notas sobre él, A. GARCía SANZ, Desarrollo y crisis del antiguo régimen en Castilla la Vieja. Economía y sociedad en tierras de Segovia de 1500 a $1814,2^{\mathrm{a}}$ ed., Madrid, 1986, p. 318 y 320; y A. de CEBALLOS-ESCALERA Y GILA, op. cit., p. 37 y 86.

${ }^{9}$ XII. Segovia. ACS, B-329, fols. 21 v - 22 r. Ed. Villar, doc. 4, cit. Colmenares, vol. I, p. 219. Colmenares dató este documento de un modo arbitrario en 1116, fecha seguida por todos los autores posteriores. De hecho, lo único seguro es que Alfonso I el batallador confirmó esta donación concejil en 1122, ACS, 1-3, ed. COLMENARES, vol. I, pp. 227-228 y VILLAR, doc. 7.

${ }^{10} 1123$, noviembre, 11. ACS, B-329, fols. 2 r - 2 v. Ed. COLMENARES, vol. I, pp. 230-231 y VILLAR, doc. 9.

"1124, marzo, 21. Toledo. ACS, 2-5. Ed. ColmENARES, vol. I, pp. 278-279, que equivoca la fecha y sitúa el documento en 1155; y VILLAR, doc. 47, que también data erroneamente el documento, colocándolo en 1154 . Bobadilla, cuya localización no he podido determinar con exactitud, se encontraba çerca de Yllescas, ACS, H-128. Para la identificación de Elesches por Illescas, Biblioteca Nacional, ms. 13.098, fols. 93 r - 94 v. 
Revenga cum ea villa que iuxta est sita Lagunelas"12, es decir, la villa de Laguna de Contreras y la parroquia de San Pedro de Revenga, parroquia que a mediados del siglo XIII era ya tan solo un despoblado ${ }^{13}$. En 1133 el obispo de Segovia cedía al monasterio de Santa María de la Sierra un tercio del territorio que le había sido donado por el concejo de Segovia y confirmado por Alfonso VII en 1122, y que consistía en "termino de Piron usque ad semitam que vadit de Torodano ad Butraco et de carrera de Septem Pulveca usque ad serra"14. En 1136 el propio monarca entregaba al titular de la sede segoviana "nostrum castellanum cui est nomen Calatalif"15, y "nostram villam cui est nomine Girondoth", Gerindote, en Toledo ${ }^{16}$. Respecto a Calatalifa, el obispo don Pedro declaraba tras la donación que el arzobispo de Toledo le había concedido la jurisdicción episcopal sobre las iglesias y clérigos de este territorio sólo de por vida ${ }^{17}$. El castillo de Calatalifa, del que actualmente sólo se conservan algunos restos, se encontraba en el término de Villaviciosa de Odón, en Madrid ${ }^{18}$. En 1137 Alfonso VII colocaba bajo la jurisdicción episcopal la villa que dicitur Morcheles $^{19}$. Ese mismo año donaba a don Pedro, arcediano de Segovia, la villa de Salzedon junto al río Cega ${ }^{20}$. Este arcediano fue luego nombrado obispo de Palencia y al tratarse de una donación personal parece razonable que trasladara la posesión de la villa a aquella diócesis. En todo caso no vuelven a aparecer referencias a Salzedon en la documentación segoviana.

\footnotetext{
${ }^{12}$ ACS, B-329, fol. 3 v, Ed. VILLAR, doc. 15, se trata de una copia sin fechar. En 1130 el propio Alfonso VII confirmaba la donación, ACS., B-329, fols. $3 \mathrm{r}-3 \mathrm{v}$, ed. VILLAR, doc. 16.

${ }^{13}$ G. MARTínez DíEz, op. cit., p. 512.

${ }^{14} 1133$, febrero, 3. Segovia. Ed. Colmenares, vol. I., pp. 236-237 y Villar, doc. 17.

${ }^{15} 1136$, octubre, 27. Palencia. ACS, B-329, fols. 6 v - 7 v. Ed. ColmEnARES, vol. I, pp. 247-248, y VILLAR, doc 21. El monarca informó de esta donación a los concejos de Segovia, Avila, Toledo y Madrid, ACS, B-329, fols. 7 v - 8 r, ed. VILLAR, doc. 49.

${ }^{16} 1136$, octubre, 27. Palencia. ACS, B-329, fols. 4 v - 5 r. Ed. VILLAR, doc. 22. 36.

${ }^{17}$ F.J. HERnández, Los cartularios de Toledo. Catálogo documental, Madrid, 1985, doc.

${ }^{18}$ VV.AA. Castillos, fortificaciones y recintos amurallados de la Comunidad de Madrid, Madrid, 1993, pp. 146-147.

${ }^{19} 1137$, octubre, 3. Hiberum. ACS, 1-11. Ed. Colmenares, vol. I. pp. 250-251 y Villar, doc. 24. En una confirmación de esta donación el propio Alfonso VII en 1139 la denomina Morquelos, ACS, 1-13, ed. VILLAR, doc. 29 y cit. COLMENARES, vol. I, p. 253. No me parece que la identificación que hace Colmenares de este lugar de Morcheles o Morquelos con Móstoles tenga base alguna.

${ }^{20} 1137$, diciembre, 14. Segovia. ACS, 1-12. Ed. ColmEnARES, vol. I, p. 260 , nota 15 , y VILLAR, doc. 25.
} 
De nuevo Alfonso VII entregaba en 1139 al obispo "Aldea Ferrariorum que iacet inter Fresno et Septem Publicam", es decir Riaza ${ }^{21}$. También en 1139 el obispo don Pedro cedía a Munio Vela el término de Collado Hermoso con la condición "que la pobles a for de poblador de Segovia et facias tal servicio qual facit in vivin de Sotos Albos a mi et a mia ecclesia et des decima ad refectorio de Sancte Marie", desapoderándose de este modo del señorío del lugar, aunque manteniendo algunos derechos sobre el mismo ${ }^{22}$.

En 1140 "Sancia, soror Adefonsi imperatoris", donaba Alcazarén al obispo de Segovia en agradecimiento por cierto préstamo que recibió del mismo y "pro pace et concordia ecclesie palentine et secobiensis"23. En 1144 Alfonso VII extendía la jurisdicción del obispo a "eum locum quem dicum Freguecedo existente intra turrem de Monsteles et illam carreram que itur de Magerido ad Ulmos", es decir a Fregacedos ${ }^{24}$. Dos años después, en 1146, el mismo monarca donaba a don Juan, arcediano de Segovia, y a Arnaldo de Corbín, canónigo toledano, la villa de Arcicóllar en Toledo para que la poblaran ${ }^{25}$. En 1151 don Juan, ahora obispo de Osma, y el mencionado Arnaldo de Corbín se repartían la posesión de la villa ${ }^{26}$. Al tratarse de una donación personal, con el traslado de don Juan a Osma es muy posible que el señorío de la villa pasase a aquella diócesis. En todo caso, en la documentación referente a Segovia no se vuelve a encontrar referencia alguna a Arcicóllar. En 1149 Alfonso VII, junto con su hijo Sancho, donaban al obispo segoviano "Pozolos populationem faciatis", esto es Belmonte de $\mathrm{Tajo}^{27}$. Al año siguiente le entregaba Receixada, "que est in

\footnotetext{
${ }^{21} 1139$, marzo, 26. Olmedo. ACS, B-329, fols. 9 r-9 v. Ed. VILLAR, doc. 27 y cit. COLMENARES, vol. I, p. 252, que se equivoca al identificar el lugar con Valdeherreros, distante de Sepúlveda seis leguas al norte.

${ }^{22} 1139$, abril, 28. Segovia. ADS, pergamino $n^{\circ} 3$. Ed. COLMENARES, vol. I, pp. 252-253 y VILLAR, doc. 28. doc. 32 .

${ }^{2} 1140$, enero, 30. Valladolid. ACS., 1-13. Ed. Colmenares, vol. I, p. 254 y VILLAR,

${ }^{24} 1144$, marzo, 3. Segovia. Ed. Villar, doc. 36, y cit. Colmenares, vol. I, p. 268. Fregacedos: despoblado en la provincia de Madrid, partido judicial de Getafe, término judicial de Getafe, término jurisdiccional y a media legua al oeste de Fuenlabrada. P. MADOZ, Diccionario geográfico-estadístico-histórico de España y sus posesiones de ultramar, vol. VIII, Madrid, 1847, p. 174.

${ }^{25} 1146$, mayo, 6. Toledo. F.J. HERNÁNDEZ, op. cit., doc. 56.

${ }^{26} 1151$, junio, 17. F.J. HERNÁNDEZ, op. cit., doc 79.

${ }^{27} 1149$, diciembre, 7. ACS, B-329, fols. 17 v. -18 r. Ed. ColmENARES, I, p. 275, y VILlaR, doc 43. Este lugar era denominado antes Pozuelo de la Soga' o de Belmonte. P. MADOZ, op. cit., IV, Madrid, 1846, p. 141.
} 
termino de Bavina", donde se une el Jarama con el Tajo ${ }^{28}$. También en 1150 donaba a obispo y cabildo el castillo que llamaban "Cervera et iacet in ripa illius fluvi qui vocatur Senares inter Alcala et Ribas", conocido actualmente como de Aldovea ${ }^{29}$. En 1154 el propio Alfonso VII cedía a don Juan, antiguo obispo de Segovia y ahora arzobispo de Toledo, el pueblo y castillo de Rivas y el castillo de Cervera o Aldovea, "satisfaciendo a nuestros obispos"30. Sancho III concedió a la iglesia de Segovia la villa de Navares de las Cuevas cum villanis suis en $1158^{31}$. En 1161 Alfonso VIII entregó al obispo la cuarta parte de las rentas reales de la ciudad de Segovia a cambio de "Calatalipha quam dono secobiensi concilio"32. El mismo monarca realizaba en 1181 otro cambio por el que cedía al obispo Mojados y Fuentepelayo a cambio de Alcazarén ${ }^{33}$. Mojados había pertenecido desde 1175 al obispo y cabildo de Palencia por donación de Alfonso VIII ${ }^{34}$, y contaba con un fuero otorgado por el prelado palentino Raimundo ${ }^{35}$.

En 1204 Alfonso VIII, encontrándose muy enfermo, realizó testamento en la villa de Fuentidueña. Entre otras disposiciones, ordenaba la fundación de un aniversario en la catedral de Segovia, al que dotaba con la villa de Fresno, Fresno de Cantespino, donde rogaba a obispo y cabildo que construyeran un castillo ${ }^{36}$. Aunque finalmente el monarca superó su

${ }^{28} 1150$, febrero, 12. Burgos. ACS, 2-3. Ed. Villar, doc. 45 , y cit. Colmenares, I, p. 423, nota 96.

${ }^{29} 1150$, diciembre, 13. Segovia. ACS, 2-4. Ed. COLMENARES, vol. I, p. 276, que identifica este castillo de Cervera con el actual de Aldovea, y VILlaR, doc. 46.

${ }^{30} 1154$, julio, 11. Segovia. Cit. Colmenares, I, p. 277. Rivas pertenecía al obispo de Palencia y el castillo de Cervera o Aldovea al de Segovia.

${ }^{31} 1158$, julio, 13. Segovia. ADS, pergamino $n^{0} 4$, y ACS, B-329, fol. 20 r. Ed. Colmenares, I, p. 286, y Villar, doc 58.

321161, marzo. Segovia. ACS, B-329, fols. 20 r-20 v. Ed. COLMENARES, I, pp. 288-289 y ViLlar, doc. 62 .

${ }^{33} 1181$, mayo, 31. Carrión. ADS, pergamino n 6. Ed. Colmenares, I, pp. 305-306, y VILLAR, doc. 76.

${ }^{34} 1175$, noviembre, 17. Segovia. Cit. Colmenares, vol. I, p. 295.

${ }^{35} \mathrm{ACS}, \mathrm{B}-329$, fols. 24 v. $-25 \mathrm{v}$. Ed. VILLAR, doc. 73 . El fuero aparece datado el 8 de enero de 1175 , pero se trata sin duda de un error del copista, pues la donación al obispo palentino se realizó el 17 de noviembre de 1175 . En todo caso, el fuero ha de ser anterior a 1181, año en que Mojados pasó al obispo de Segovia.

${ }^{36} 1204$, diciembre, 8. Fuentidueña. Reg. F.J. FERNÁNDEZ, op. cit., doc. 282 y VILLAR, doc. 100, que lo data erroneamente en 1208. Cit. Colmenares, I, p. 326. Los autores que han tratado sobre este particular identifican este Fresno con Fresno de Cantespino, así M. GoNZÁLEZ Bartolomé, Riaza. Datos históricos y documentos, "Estudios Segovianos", IX (1957), p. 445, o A. de Ceballos-Escalera y Gila, op. cit., pp. 74-75. 
enfermedad, decidió que se mantuviera esta donación, lo que no impidió que el señorío eclesiástico sobre esta villa durara poco, ya que en 1214 Enrique I recuperó su autoridad sobre la misma entregando al obispo "hereditatem sufficientem ad viginti iuga bovum ad anni vicem in serna mea de Magan" a cambio de ella ${ }^{37}$. En 1209 Alfonso VIII confirmaba a la iglesia de Segovia la compra de Luguillas a Blasco Miguel de Avila y su mujer Urrrexa "pro mille et sexcentis morabetinis"38.

De este modo se puede dar por finalizado el proceso de formación del señorío de los prelados segovianos, que en los inicios del siglo XIII presentaba ya muchas de las características que le definirían durante el resto de la Edad Media, destacando entre ellas su dispersión territorial, reflejada en el hecho de que se extendiera por las actuales provincias de Valladolid, Segovia, Madrid y Toledo.

La dotación de señorío a los obispos de Segovia se complementó con la entrega a los mismos de una serie de privilegios, especialmente exenciones de tipo fiscal, y de bienes, como rentas y heredades, que contribuyeron en gran medida a fortalecer la posición económica de los prelados segovianos.

Entre las exenciones fiscales destaca la otorgada en 1147 por Alfonso VII, que liberaba a los vasallos de señorío eclesiástico de la diócesis de Segovia del pago de todo tributo real o secular ${ }^{39}$. Tres años después situaba además a las villas y cualquier otras posesiones eclesiásticas al margen de todo derecho o dominio secular ${ }^{40}$. Las donaciones de bienes son muy numerosas y se inician en fecha temprana. En 1122 Alfonso I de Aragón cedía a obispo y cabildo una heredad en Segovia sub kastro junto al río Eresma $^{41}$. Dos años después Alfonso VII entregaba al obispo una huerta

\footnotetext{
${ }^{37} 1214$, diciembre, 18. Burgos. Ed. Colmenares, I, pp. 347-348, y Villar, doc. 102. El propio Enrique I confirmaría este cambio un mes después, ed. VILLAR, doc. 104, y cit. COLMENARES. I, p. 348.

${ }^{38} 1209$, marzo, 13. Peñafiel. ACS, 3-14. Ed. VILLAR, doc. 101, y cit. COLMENARES, I, p. 333. Luguillas: despoblado en la provincia de Valladolid, partido judicial de Olmedo, término jurisdiccional de Mojados. P. MADOZ, op. cit., X, Madrid, 1847, p. 462. 271.

${ }^{39} 1147$, marzo, 25. Segovia. ACS, 1-18. Ed. VILlar, doc. 39, y cit. Colmenares, I, p.

${ }^{40} 1150$, febrero, 12. Burgos. ACS, 7-3. Ed. VILLAR, doc. 44. $\mathrm{n}^{\circ} 7$

${ }^{41} 1122$, diciembre. Fresno. ACS, 1-3. Ed. Colmenares, I, pp. 227-228, y Villar, doc.
} 
bajo el alcázar y una serna entre Fuentepelayo y Navalmanzano ${ }^{42}$. En 1135 el mismo monarca donaba a obispo y cabildo la décima de todos los bienes reales de la diócesis y la tercera parte de la moneda que fuera hecha en Segovia ${ }^{43}$, y al año siguiente una serna sobre el río Eresma entre "Tormam" y "Sanctum Petrum de Caldes"44. En 1140 la infanta doña Sancha donaba al obispo el monasterio de San Martín de Grajal, entre Zamora y Sahagún. Cuatro años después Alfonso VII donaba al obispo una serna sobre el río Milanos y todas las posesiones reales en Cogeces de Iscar y Megeces, para compensar al prelado de las pérdidas territoriales que había sufrido frente a la diócesis de Palencia ${ }^{45}$. En 1147 entregaba al obispo la heredad de Pharagii Adalil en la recién conquistada Calatrava y la de Ibenzohar ${ }^{46}$. En 1158 Sancho III daba a obispo y cabildo meum "alcaçar quod est Secobie" a cambio de unas casas en la Almuzara ${ }^{47}$. Alfonso VIII donaba a obispo y cabildo en 1171 una serna en Pedraza ${ }^{48}$. En 1190 el obispo de Segovia obtenía cien áureos del obispo de Palencia en las salinas de Belinchón, en compensación por la pérdida frente a éste de Portillo y Peñafiel $^{49}$, que Alfonso VIII cambiaría ese mismo año por otros cien áureos sobre el portazgo de Segovia ${ }^{50}$. En 1200 Alfonso VIII confirmaba a obispo y cabildo las décimas del portazgo de Sepúlveda, Cuéllar, Coca, Iscar,

\footnotetext{
${ }^{42} 1124$, enero, 28. Avila. ACS, B-329, fols. 18 v-19 r. Ed. COLMENARES, I, pp. 277-278, que equivoca la fecha y sitúa el documento en 1155 , y VILLAR, doc. 48 , que también data erroneamente el documento en 1155 .

${ }^{43} 1135$, marzo, 27. ACS, 1-7. Ed. VILlar, doc. 18.

${ }^{44} 1136$, octubre, 25. Palencia. ACS, 1-9. Ed. COLmenares, I, p. 247 y pp. $258-259$, nota 2 , y VILLAR, doc. 20

${ }^{45} 1144$, marzo, 3. Segovia. Archivo Histórico Nacional, Clero, carpeta 1957, $\mathrm{n}^{\circ} 13$, y ACS., B-329, fols. 12 r - 13 r. Ed. Colmenares, I, pp. 267-268, y Villar, doc. 35.

${ }^{46} 1147$, enero, 9. Calatrava. ACS., 1-17. Ed. Colmenares, I, p. 270, y VIllar, doc. 38.

${ }^{47} 1158$, julio, 13. Segovia. ACS., B-329, fols. 19 v - 20 r. Ed. VILLAR, doc. 59.

${ }^{48} 1171$, enero, 25, Medinaceli. ACS, 2-14. Ed. VILLAR, doc. 71.

${ }^{49} 1190$, marzo, 17. Palencia. ACS, 3-3. Ed. VILLAR, doc. 84.

${ }^{50} 1190$, diciembre, 3. Toledo. Archivo Histórico Nacional, Clero, carpeta 1957, $\mathrm{n}^{\circ} 15$. Ed. VILLAR, doc. 86 , y cit. ColmENARES, I, p. 313, que se confunde cuando dice que lo que cambian los obispos de Segovia es la villa de Rivas, que nunca había pertenecido a esta diócesis, sino a la palentina, y además era desde 1154 del arzobispo de Toledo.
} 
Pedraza, Maderuelo, Fresno, Fuentidueña, Bernuy y Sacramenia ${ }^{51}$. Dos años después donaba al obispo unas casas en Maderuelo ${ }^{52}$.

Los conflictos de los lugares de señorío episcopal con las instituciones circundantes debieron comenzar muy pronto, y así el rey Alfonso VII se vio obligado a expedir una carta protegiendo a Riaza contra el concejo de Ayllón, "qui vos meam elemosinam contrariatis et vetatis"53. En 1182 Alfonso VIII, con seguridad a consecuencia de un pleito, disponía que los ganados del obispo y la iglesia de Segovia pudieran pastar en los mismos lugares que utilizaban los vecinos de Sepúlveda ${ }^{54}$. En 1196 Alfonso VIII dictó una sentencia para que la villa de Navares de las Cuevas volviera "iure hereditario et irrevocabiliter" a poder del obispo de Segovia, ya que su antecesor la había enajenado a favor de Sepúlveda sin consentimiento del cabildo $^{55}$. El propio monarca confirmaba en 1207 el acuerdo entre Sepúlveda y Fresno de Cantespino, en ese momento todavía de señorío eclesiástico, sobre la delimitación de los pastos de aprovechamiento común ${ }^{56}$.

Por su parte, los diferentes prelados también debieron mantener conflictos de mayor o menor entidad con los pueblos de su señorío y así, por ejemplo, en 1161 el obispo don Guillermo realizaba un pacto con los habitantes de Gerindote por el que el prelado mantenía "medietatem predicte ville" incluida la fortaleza, "turrem", mientras que los vecinos se quedaban con "nostri aliam medietatem" y el privilegio de ser juzgados por "toletani iudiçis" 57 .

Como se ha podido apreciar, el señorío temporal de los obispos de Segovia comenzó a formarse en cuanto se consagró un nuevo obispo para la restaurada diócesis, alcanzando ya una configuración bien definida a fines del siglo XII. En esta labor de creación destacó, sin duda, la generosidad de

\footnotetext{
${ }^{51} 1200$, mayo, 23. Segovia. Archivo Histórico Nacional, Clero, carpeta 1957, no 16. Ed. VILlAR, doc. 90, y cit, COLMENARES, I, p. 317.

521202, mayo, 25. San Esteban. ACS., 3-10. Ed. Villar, doc. 97, y cit. Colmenares, I, p. 325 .

${ }^{-53}$ Siglo XII. ACS., B-329, fol. 24 r. Ed. VILlaR, doc. 50.

${ }^{54} 1182$, octubre, 11. Medina del Campo. ACS, 2-20. Ed. Colmenares, I, p. 308, y VILLAR, doc. 79.

${ }^{55} 1196$, octubre, 29. Santa Eulalia. ACS, B-302-bis, fols. 5 v.-6 r. Ed. VILLAR, doc. 88, cit. Colmenares, I, p. 315.

${ }^{56} 1207$, julio, 20. Riaza. Ed. SEPÚvedA, doc. 6.

${ }^{57} 1161$, febrero. ACS, B-329, fols. 22 v.-23 r. Ed. VILLAR, doc. 61 , y cit. ColmENARES, I, p. 289.
} 
los monarcas, pues tan solo tres de las incorporaciones no fueron realizadas por ellos, la donación de Sotosalbos por el concejo de Segovia, la de Alcazarén por la infanta doña Sancha y la compra de Luguillas por la propia Iglesia segoviana. También conviene resaltar la importancia individual de las donaciones de Alfonso VII que constituyeron, de hecho, el grueso del señorío episcopal.

\section{SIGLOS XIII, XIV Y XV. EVOLUCIÓN Y CONFLICTIVIDAD}

En 1216 Honorio III confirmaba al cabildo la entrega que el obispo don Gerardo le había hecho de la villa de Aguilafuente, que pasó a constituir la primera propiedad del nuevo señorío capitular ${ }^{58}$. Al menos desde 1220 , Pelayos del Arroyo también formaba parte de este señorío, aunque resulta desconocida sú procedencia y su modo de adquisición ${ }^{59}$. También se desconoce el momento concreto en que Sotosalbos se unió a la jurisdicción capitular, procedente de la episcopal, pero al menos desde 1247, año en que se produjo la separación de mesas entre el obispo y el cabildo, estaba plenamente integrada entre las posesiones catedralicias ${ }^{60}$. Así pues, desde mediados del siglo XIII y hasta 1536 , el cabildo poseería en señorío las villas de Aguilafuente, Pelayos del Arroyo y Sotosalbos.

Tras la mencionada división de mesas de 1247 el señorío de los obispos de Segovia estaba formado ultra serram por Belmonte de Tajo, Bobadilla, Gerindote y Mejorada del Campo; y citra serram por Caballar, Fuentepelayo, Laguna de Contreras, Luguillas, Mojados, Navares de las Cuevas, Riaza y Turégano ${ }^{61}$. Al grupo de villas al norte de la sierra se uniría Veganzones en fecha y circunstancias desconocidas ${ }^{62}$.

\footnotetext{
${ }^{58} 1216$, julio, 4. Anagni. ACS, 3-16. Ed. VILLAR, doc. 106.

${ }^{59} 1220$, enero (Segovia). ACS, 4-3. Ed. VILLAR, doc. 112.

${ }^{60} 1247$, septiembre, 14. Lyon. ACS, B-291. Ed. Villar, doc. 141, y cit. Colmenares, I, p. 378.

${ }^{61} 1247$, septiembre, 14. Lyon. ACS, B-291. Ed. VILLAR, doc. 141, y cit. ColmenareS, I, p. 378. En este documento se encuentra la primera mención de Mejorada del Campo, de la que no se conoce ni el momento de su integración en el señorío episcopal ni el modo en que se produjo.

${ }^{62}$ Colmenares, I, p. 436. Cita Veganzones como integrante del señorío episcopal hacia 1291, pero creo que sin una base documental que lo respalde. La primera mención explícita de esta villa como parte del señorío que he encontrado es de 1405, en SEPÚLVEDA, doc. 98, y
} 
Como se puede apreciar, algunos de los lugares integrantes de este señorío durante el siglo XII ya no pertenecían al mismo, unos por cesión a otras instituciones o a particulares, como Aguilafuente, Collado Hermoso y Sotosalbos; otros por haber sido recuperados por distintos monarcas a cambio de otras villas o rentas, como Alcazarén, el castillo de Aldovea, Calatalifa, Fresno de Cantespino e Illescas; y un último grupo por causas desconocidas, Fregacedos, Morcheles y Receixada. A pesar de todo, la mayor parte de las villas situadas al norte de la sierra que habían integrado durante el siglo XII el señorío episcopal, constituían ahora el núcleo del dominio territorial de la iglesia, formando "una amplia franja territorial que se extendía desde el piedemonte del sistema central hacia el noroeste, siguiendo la línea marcada por el río Pirón"63.

Como dato complementario para evaluar la situación del señorío, conocemos la población de algunas de sus villas en 1260: "Anno domini MCCLX...estos son los veçinos delas villas del obispo de aquende sierra. En Riaça XLII veçinos e medio. En Navares XX veçinos e medio. En Laguniellas XX veçinos e medio. En Sotos Albos LXXX veçinos. En Cavallar XXX veçinos e medio. En Turuegano çient veçinos. En Vaguila Fuente LXXX e VIII veçinos. En Fuente Pelayo LXVIII. En Moiados L veçinos. Suma por todos quinientos" ${ }^{64}$. A modo de comparación, puede señalarse que a mediados del siglo XV sobre un total de ciento cincuenta y ocho pueblos de la tierra de Segovia no se encontraron más de dos mil vecinos $^{65}$

La configuración territorial del señorío episcopal permanecería estable hasta finales del siglo XVI excepto por la salida del mismo de Riaza. Esta villa fue separada del señorío por venta al monarca en 1430. Juan II adquirió la mencionada villa al obispo don Juan a cambio de "syeteçientos e setenta florines de oro del cuño de Aragón de justo peso e por ellos treynta e ocho mill e quinientos maravedíes de la moneda que agora se usa sobre las alcabalas de Turégano, Fuentepelayo, Caballar y Veganzones"66.

RIAZA, doc. 27.

${ }^{63} \mathrm{M}$. Santamaría Lancho, op. cit., p. 446.

${ }^{64}$ ACS, B-291. Se trata de una anotación realizada en el recto del primer folio.

${ }^{6.5}$ VV.AA. Historia de Segovia, Segovia, 1987, p. 60

${ }^{66} 1430$, junio, 20. Burgo de Osma. ADS, leg. 118. Reg. SEPúlvedA, doc. 230. 
Durante toda esta etapa los vasallos del señorío eclesiástico y los titulares del mismo se vieron beneficiados de nuevo por los distintos monarcas con un gran número de privilegios y exenciones.

En 1221 Fernando III concedía al obispo y cabildo de Segovia "quod quicumque homines de Secovia vel de aliis locis undecumque sint qui habuerint hereditatis in villis episcopis vel canonicorum de Secovia quod pectent pro illis in omnibus pectis que habitatores predictam villarum pectaverint ${ }^{167}$. En 1272 Alfonso $X$ concedía a los ganados del obispo de Segovia que pudieran pastar libremente por el reino "asy como los míos mesmos" $^{\prime 68}$. Al año siguiente, este monarca confirmó a obispo y cabildo la práctica totalidad de los bienes y privilegios de que disfrutaban. Sin duda esta generosidad real se debía al apoyo que el rey Alfonso estaba recibiendo de los segovianos en su lucha contra los nobles rebeldes y a los servicios que en el "fecho del imperio" le estaba prestando el obispo de Segovia, Fernando Velázquez. En 1277 Alfonso X concedió a las villas de señorío del obispo de Segovia que no pagasen los pechos foreros que debían al monarca, "por este servicio que nos agora prometieron"69. Al año siguiente el mismo monarca concedía al cabildo que pudiera comprar con los quince mil maravedíes obtenidos por la venta de una heredad al propio Alfonso, otra con los mismos derechos en el realengo ${ }^{70}$. Fernando IV concedió en 1304 a Riaza un mercado todos los lunes ${ }^{71}$. En 1314 Alfonso XI concedía al obispo Fernando Sarracín la mitad de los pechos que los vasallos de señorío episcopal debían dar al monarca, excepto seis mil maravedíes por acémilas y yantar y la moneda forera de siete en siete años ${ }^{72}$. Dos años después y anté la queja de los eclesiásticos, el rey ordenó que se respetasen los privilegios y beneficios que éstos habían obtenido de Sancho IV y Fernando $\mathrm{IV}^{73}$. En 1326 confirmaba las exenciones y privilegios de las propiedades

\footnotetext{
${ }^{67} 1221$, junio, 2. Segovia. Ed. Colmenares, I, pp. 161-162, y VILlar, doc. 114.

${ }^{68} 1272$, octubre, 20. Burgos. ACS, B-302-bis, fols. 9 r. -9 v.

${ }^{69} 1277$, julio, 7. Burgos. ACS, 7-14-bis. Ed. Colmenares, I, pp. 412-413, y VILlar, doc. $\mathrm{n}^{\circ} 198$.

${ }^{70} 1278$, septiembre, 24. Segovia. ACS, 7-15. Ed. Villar, doc. 200, y cit. Colmenares, I, p. 413, que interpreta mal el documento y lo considera un privilegio de quince mil maravedies de juro, error seguido por Villar.

${ }^{71} 1304$, mayo, 16. Burgos. Ed. RIAZA, doc. 8.

${ }^{72} 1314$, julio, 10. Valladolid. ACS, B-329, fols. 26 v. -28 r.

${ }^{73} 1316$, abril, 18. Toro. Ed. CUÉllar, doc. 71, y reg. SANZ, doc. 244.
} 
eclesiásticas aunque provinieran del realengo ${ }^{74}$. Cuatro años después concedía a obispo y cabildo que no pagasen yantar, salvo sus vasallos que debían hacerlo todos en uno ${ }^{75}$. En 1342 obispo y cabildo decidieron servir de modo extraordinario ese año y el siguiente los tributos de acémilas y fonsadera de sus vasallos, para contribuir a la campaña que el rey iba a iniciar en Andalucía. Alfonso XI en agradecimiento les confirmó el privilegio de Sancho IV de que por razón de acémilas no pagaran más que seis mil maravedíes anuales ${ }^{76}$. En 1348 Alfonso XI concedía al concejo de Sotosalbos un terreno "por defesa e por exido" para que llevaran allí sus ganados con toda libertad y esperando que con esta medida "dicho lugar se pueble meior"77. Pedro I en 1351 ordenaba a los cogedores del portazgo de Sepúlveda que no lo cobrasen a los vecinos de Riaza ${ }^{78}$. Dos años después ratificó que los pueblos del obispo y cabildo al norte de la sierra no pagasen por acémilas y fonsadera más que los seis mil maravedíes estipulados. En 1361 el mismo monarca concedía a algunos de los pueblos de señorío episcopal y capitular la tenencia de noventa ballesteros "quitos de todo pecho e pedido e fonsadera", con la condición de que estuvieran "prestos para ir en mi servicio ende que los llamare o enviare llamar"79. Enrique II en 1367 realizaba una confirmación general de los privilegios de que gozaba Riaza $^{80}$.

Además de las concesiones reales, las villas de señorío episcopal debieron gozar con toda seguridad de una serie de exenciones y privilegios otorgados por sus señores, los prelados segovianos, que aunque de un alcance más limitado que las concesiones de los monarcas contribuirían a aliviar a los vasallos de la enorme carga fiscal que suponía la sujección a las diferentes jurisdicciones existentes en la Edad Media. Así, en 1381 don Hugo, obispo de Segovia, confirmaba a sus vasallos de Turégano el privilegio que tenían concedido por los prelados anteriores de que no se

\footnotetext{
${ }^{74} 1326$, julio, 28. Medina del Campo. ACS., 11-11. Reg. SANZ, doc. 253.

${ }^{75} 1330$, octubre, 28. Sevilla. ACS, 11-15 y 11-16. Reg. SANZ, docs. 256 y 257.

${ }^{76} 1342$, mayo, 16. Segovia. ACS, B-302-bis, fols. 15 v.-16 v. Cit. COLMENARES, I, p. 477.

${ }^{77} 1348$, agosto, 25. Rascafría. ACS, 12-14. Reg. SANZ, doc. 276.

${ }^{78} 1351$, diciembre, 6. Valladolid. Ed. SEPÚlVEDA, doc. 191 y RIAZA, doc. 15.

${ }^{79} 1361$, febrero, 12. Almazán. Ed. V. BorReGUero ViRSEDA, op. cit., pp. 61-65.

${ }^{80} 1367$, febrero, 20. Burgos. Ed. RIAZA, doc. 18.
} 
empadronase al mayordomo ni a los vecinos "en ningun pecho nin pedido nin tributo" 81 .

Desde los últimos años del siglo XIV el señorío episcopal no recibiría ya más privilegios y exenciones de importancia, obteniendo tan solo pequeñas concesiones puntuales $\mathrm{y}$, sobre todo, confirmaciones de los beneficios de que ya gozaba.

Como señores de vasallos, los obispos de Segovia no tuvieron que hacer frente a conflictos de verdadera entidad. En todo caso, y para entender mejor la dinámica de sus posesiones señoriales, los problemas a que debieron enfrentarse pueden dividirse en varias categorías: los originados por la utilización de aguas, pastos y otros recursos similares; los derivados de las usurpaciones territoriales; los provocados por la delimitación de los términos entre concejos contiguos; los motivados por los recaudadores de rentas reales; los causados por el choque entre jurisdicciones diferentes; y los originados entre los propios obispos y sus vasallos.

El uso de los recursos naturales siempre constituyó una fuente de conflictos. En 1221 Fernando III ratificaba el acuerdo entre el arzobispo de Toledo, don Rodrigo, administrador del obispado en ese momento, y una serie de pueblos sobre el modo de regar, utilizando las aguas del río Pirón, los linares y huertas que los obispos de Segovia tenían junto a su palacio de Collado Hermoso ${ }^{82}$. En 1257 el concejo de Segovia y las villlas de señorío episcopal y capitular llegaban al acuerdo de que éstas pudieran pastar con libertad dentro de los límites territoriales segovianos con la condición de no llevar consigo ganado de "ffuera de término"83. Don Raimundo de Losana, obispo de Segovia, realizó en 1258 una avenencia entre sus vasallos de Riaza y el concejo de Sepúlveda sobre la utilización de la madera de los términos de este último y otros asuntos ${ }^{84}$. En 1275 Alfonso X confirmaba una concordia sobre aprovechamiento de madera y pasto entre Riaza y Fresno ${ }^{85}$. $\mathrm{Al}$ año siguiente ratificaba al concejo de Cuéllar la posesión de ciertos

\footnotetext{
${ }^{81} 1381$, junio, 5. Turégano. ADS, pergaminos, $n^{\circ} 8$.

${ }^{82} 1221$, junio, 10. Segovia. ACS, 11-17-bis. Reg. Villar, doc. 115, y cit. Colmenares, I, p. 358.

${ }^{83} 1257$, mayo, 1. Segovia. ACS, 10-10. Reg. SANZ, doc. 229, y VILlar, doc. 162, y cit. Colmenares, I, p. 399.

${ }^{84} 1258$, febrero, 14. Valladolid. ACS, B-302-bis, fols. 16 v-18 r. Ed. SEPÚlvedA, doc. 9 , y RIAZA, doc. 1.

${ }^{85}$ 1275. Reg. RIAZA, doc. 2.
} 
pinares, anulando una mi carta arrebatada, que se la concedía a Aguilafuente y Fuentepelayo ${ }^{86}$. En 1298 el concejo de Sepúlveda se comprometía a respetar el acuerdo realizado con el de Riaza por el que permitía a este último introducir ganado en su territorio ${ }^{87}$. Fernando IV ordenaba en 1305 a Riaza que "non labreis nin corteis nin pasteis vuestros ganados" en el territorio de Fresno ${ }^{88}$. En 1327 Alfonso XI, por el contrario, se veía obligado a proteger a Riaza de los concejos de Sepúlveda, Ayllón y Fresno, porque éstos "pescaban e dannaban en su río e que les andaban sus montes propios entre sus labores e les pasaban las dehessas faziéndoles agravamientos muchos"89. En 1346 el concejo de Segovia, ante las quejas de obispo y cabildo, confirmó a los vecinos de Aguilafuente, Pelayos del Arroyo, Sotosalbos y Fuentepelayo el uso de los pastos y montes segovianos con todos los derechos ${ }^{90}$. Enrique II en 1367 medió a favor de Riaza en la querella que mantenía con Sepúlveda, Ayllón y Fresno sobre el aprovechamiento de las aguas y los pastos ${ }^{91}$. En 1376 este monarca ordenaba al concejo de Sepúlveda que cumpliera sus acuerdos y permitiera a los vecinos de Riaza llevar sus ganados a pacer y beber a su tierra, instándoles además a que devolvieran los ganados y prendas que les habían tomado por esta razón ${ }^{92}$. El obispo don Hugo concedía en 1378 a su vasallo Antón Sánchez un enterramiento en el coro de la iglesia de Santa María de Fuentepelayo, en premio a la labor que había realizado como procurador de esa villa "sobre rrazón delas peleas e muertes e muchos dannos que nos fazían los de Cuéllar ffasta aquí"93. En 1388 se realizó una concordia entre los concejos de Caballar y La Cuesta por tres años sobre los daños que los ganados pudieran causar en viñas, prados o dehesas ${ }^{94}$. Enrique IV en 1468 ordenaba al concejo de Segovia que respetase los derechos sobre las aguas de los ríos Pirón y Pironcillo de diversos pueblos, entre ellos Pelayos del Arroyo y

\footnotetext{
${ }^{86} 1276$, abril, 28. Burgos. Ed. CuÉLlar, doc. 31.

${ }^{87} 1298$, septiembre, 24. Sepúlveda. Ed. SEPÚlvedA, doc. 187, y RIAZA, doc. 5.

${ }^{88} 1305$, mayo, 15. Medina del Campo. Ed. T. García García, Fresno de Cantespino. Síntesis histórica de una villa segoviana, Segovia, 1980, pp.38-39.

${ }^{89} 1327$, enero, 12. Sepúlveda. Ed. RIAZA, doc. 10.

${ }^{90} 1346$, febrero, 3. Segovia. Archivo Municipal de Segovia, caja 1413-19.

${ }^{91} 1367$, febrero, 20. Burgos. Ed. RiAZA, doc. 17.

${ }^{92}$ 1376, mayo, 10. Alcalá de Henares. Ed. SePÚlvedA, doc. 42-a, y RiAZA, doc. 19.

${ }^{93} 1378$, febrero, 16. Ed. S. ARribas ArribaS, Fuentepelayo, Segovia, 1984, pp. 74-76.

${ }^{94} 1388$, marzo, 14. Caballar - La Cuesta. ACS, H-113.
} 
Sotosalbos, ambos de señorío capitular ${ }^{95}$. En 1478 el consejo real envió un delegado a los concejos de Navares de Enmedio, Urueñas y Castroserracín para que respondieran de una tala realizada en un bosque de Navares de las Cuevas, villa de señorío episcopal ${ }^{96}$.

Otro de los problemas a que se enfrentaban las posesiones eclesiásticas era el de las usurpaciones por parte de los laicos. En 1227 Honorio III comisionaba al obispo de Cuenca y a los arcedianos de Madrid y Sigüenza para que lograran la restitución al obispo de Segovia de los domos y villas de su propiedad que estuvieran usurpadas por clérigos o laicos ${ }^{97}$. En 1229 Juan, legado pontificio, establecía que la villa de Gerindote permaneciera bajo la propiedad de los obispos de Segovia, a quienes se la disputaban un caballero de la orden de Santiago y su esposa, aunque estos últimos deberían recibir de los prelados segovianos setenta áureos anuales ${ }^{98}$. Gregorio IX en 1233 daba poder a los obispos de Burgos y de Osma y al deán de Burgos para que decidieran sobre el caso de ciertas posesiones del obispo de Segovia en Alcazarén que habían sido tomadas por vecinos de la villa de Olmedo, autorizándoles a dictar "excomunicationis vel interdicti" si fuera necesario $^{99}$. Al año siguiente comisionaba a los abades de Palazuelos y Sacramenia para que resolvieran sobre los diezmos de estas posesiones que todavía no habían sido devueltas ${ }^{100}$. En 1305 el obispo don Fernando mandaba publicar una bula de Bonifacio VIII de 1295 que establecía rigurosas censuras contra los usurpadores de cosas eclesiásticas y los que cargaban de tributos a la iglesia ${ }^{101}$. En 1307 Fernando IV, a petición del obispo, le confirmaba sus privilegios y ordenaba a los usurpadores e intrusos que devolvieran las casas y heredamientos que habían tomado al obispo y a las otras instituciones eclesiásticas de la diócesis ${ }^{102}$. En 1311 de nuevo el

\footnotetext{
${ }^{95} 1468$, noviembre, 15. Colmenar de Oreja. Archivo Municipal de Segovia, legajo 602-5.

${ }^{96} 1478$, marzo, 13. Sevilla. Ed. C. SÁEZ SÁNCHEZ, Colección diplomática de Sepúlveda, II (1076-1485), Segovia, 1991, doc. 157.

${ }^{97} 1227$, enero, 17. Letrán. ACS, 4-9. Ed. VILLAR, doc. 123. 368.

${ }^{98} 1229$, agosto, 17. Lerma. ACS, 4-14. Ed. VILlar, doc. 127, y cit. Colmenares, I, p.

${ }^{99} 1233$, marzo, 30. Letrán. ACS, 4-18. Ed. VILLAR, doc. 131.

${ }^{100} 1234$, julio, 5. Reate. ACS, 4-22. Ed. VILLAR, doc. 132.

${ }^{101} 1305$, abril, 21. Segovia. Ed. CUÉLlAR, doc. 56, y cit. ColmENARES, I, pp. 446-447.

1021307, agosto, 4. Burgos. ACS, 10-8. Reg. SANZ, doc. 227.
} 
obispo don Fernando realizó un "statuto perpetuo" contra aquellos que estaban realizando y realizaran "muchos tuertos e grandes dannos" a las personas y vasallos eclesiásticos y a sus bienes ${ }^{103}$. Como se puede apreciar, el inicio del siglo XIV debió ser un momento especialmente duro para las posesiones eclesiásticas en la diócesis de Segovia, pero la situación terminaría estabilizándose pues más adelante ya no se encuentran documentos que defiendan de un modo tan firme estos bienes, lo que es indicativo, sin duda, de que la presión sobre los mismos había disminuido hasta unos límites razonables.

La delimitación de los términos entre concejos contiguos también fue una continua fuente de problemas, pues era muy frecuente la pretensión de la propiedad sobre un territorio del que en muchas ocasiones existían títulos contrapuestos. En 1258 Alfonso X dictaba sentencia en el pleito entre Olmedo, Portillo y Mojados por razón de los límites y el uso comunal de determinadas tierras ${ }^{104}$. En 1273 el cabildo de Segovia, en nombre de sus vasallos de Sotosalbos, y el abad del monasterio de Santa María de la Sierra de Sotosalbos se comprometían a aceptar la sentencia que diesen los jueces nombrados por el rey Alfonso $\mathrm{X}$ sobre el pleito que mantenían por la delimitación de términos, el uso de aguas y cañadas, y la regulación de los daños causados por el ganado. En 1289 el infante don Sancho confirmaba una carta de Alfonso VIII de 1210 que señalaba los límites entre los concejos de Aguilafuente y Cuéllar ${ }^{105}$. Enrique II en 1376 dictaba sentencia en el pleito que por razón de la delimitación de términos mantenían los concejos de Fuentepelayo y Cuéllar ${ }^{106}$. En 1448 Fuentepelayo y Cuéllar llegaban a una concordia sobre mojones con la mediación del cardenal Juan de Cervantes, obispo de Segovia ${ }^{107}$. En 1459 Mejorada del Campo, del obispo de Segovia, y Loeches, del arzobispo de Toledo, lograban un acuerdo sobre la delimitación de sus respectivos términos ${ }^{108}$. En 1466 se resolvía el pleito que sobre los términos y otros asuntos mantenían Caballar y La Cuesta ${ }^{109}$.

\footnotetext{
${ }^{103} 1311$, junio, 7. Segovia. ACS, 10-17. Reg. SANZ, doc. 236.

${ }^{104} 1258$, noviembre, 5. Segovia. ACS, B-302-bis, fols. 7 r. -8 r.

${ }^{105} 1289$, febrero, 13. Palencia. Ed. CUÉllar, doc. 39.

${ }^{106} 1376$, noviembre, 7. Valladolid. ACS, 13-13. Reg. SANZ, doc. 297.

${ }^{107} 1448$. Reg. CUÉllar, doc. 270.

${ }^{108} 1459$, marzo, 7. Cit. Colmenares, II, p. 37.

${ }^{109} 1466$, julio, 24. Toledo. ACS, H-113.
} 
Una de las quejas que más se repite por parte de los eclesiásticos durante la Edad Media era la referente a las presiones a que se veían sometidos por los recaudadores de rentas reales. En 1287 el rey Sancho IV, ante las protestas que le habían sido formuladas, ordenaba a los "pesquisidores e a los entregadores del regalengo e del abadengo del obispado de Segovia" que respetaran las cartas y privilegios de la Iglesia segoviana ${ }^{110}$. En 1291 el monarca ordenaba a sus cobradores que respetasen el privilegio de los vasallos de obispo y cabildo de no pagar por acémilas más que seis mil maravedíes anuales ${ }^{111}$. Pocos días después ordenaba que tampoco se les exigiera el yantar, pues no tenían que pagarlo al rey "sinon quando acaesçiera en alguno de sus logares una vez cada anno e lo pagavan todos de conssuno"112. En 1339 una sentencia favorable a Sotosalbos eximía a sus habitantes del pago del montazgo ${ }^{113}$. A pesar de las exenciones con que contaban los lugares de señorío eclesiástico, la insistencia de los recaudadores de la diócesis por cobrar los impuestos llevó a obispo y cabildo a pedir a Alfonso XI en 1342 la confirmación del privilegio de sus vasallos de no pagar más que seis mil maravedíes por razón de acémila y fonsadera ${ }^{114}$.

Otro de los problemas inevitables en la Edad Media era el del choque entre las numerosas jurisdicciones, cuyas competencias se solapaban en muchas ocasiones por no estar plenamente definidos sus límites. En 1279 Alfonso X dictó sentencia a favor del obispo de Segovia y contra los laicos que habían arrendado alguna cosa del obispo o del cabildo y que en caso de pleito se negaban a responder ante los juezes de la iglesia, ordenándoles que así lo hicieran ${ }^{115}$. A los pocos días expedía además otra carta por la que obligaba a los jurados y alcaldes de Segovia a aceptar que el testimonio en juicio de los canónigos fuera tan válido como el de cualquier otro vecino, y no se les impidiera el acceso a montes, aguas y otros bienes comunales ${ }^{116}$. En 1293 Sancho IV, a petición de obispo y cabildo, ordenaba a los entregadores que en las villas episcopales y capitulares al realizar juicio a

\footnotetext{
${ }^{110} 1287$, septiembre, 27. Cáceres. ACS, 8-11. Ed. VILlar, doc. 210.

'"'1291, junio, 5. Burgos. ACS, 9-2. Ed. VILlar, doc. 222, y cit. Colmenares, I, p. 436.

1121291 , junio, 25. Palencia. ACS, 9-4. Ed. VILLAR, doc. 224.

${ }^{113} 1339$, agosto, 29. Segovia. Archivo Histórico Nacional, Clero, carpeta 1959, no 8.

${ }^{114} 1342$, mayo, 16. Segovia. ACS, 12-13. Reg. SANZ, doc. 275.

${ }^{115}$ 1279, enero, 9. Toledo. ACS, 8-1. Ed. VILLAR, doc. 201.

${ }^{116} 1279$, enero, 18. Toledo. ACS, 8-2. Ed. VILLAR, doc. 202.
} 
alguno de los pastores "tomedes por conpannero al alcallde que vos diere el obispo, que ssea consuno a judgar los pleitos que oviéredes a librar de los dichos vassallos"117. En algunas ocasiones los eclesiásticos utilizaban todas las armas a su alcance para hacer valer sus derechos, y así en 1405 la villa de Sepúlveda requirió al obispo don Juan para que no dictara excomunión ni entredicho sobre la villa con motivo de las disputas que mantenía con Navares de las Cuevas, Riaza, Veganzones y Turégano, lugares de señorío episcopal. Por toda respuesta, el obispo confirmó la excomunión y su mantenimiento hasta que se observaran los acuerdos anteriores entre Sepúlveda y estos lugares ${ }^{118}$. En 1445 Pelayos del Arroyo y Sotosalbos, de señorío capitular, renovaron su incorporación a la ciudad de Segovia en el sexmo de San Lorenzo ${ }^{119}$. Con toda seguridad esta reincorporación buscaba un acceso estable a todos los recursos naturales de que disfrutaban todos los pueblos de su entorno y que dependían jurisdiccionalmente del concejo de Segovia: En 1506 el provisor del obispado inició un proceso contra Lope Zorrilla, alguacil de la capitanía de Fernando de Bobadilla y aposentador de esa tropa, por haber entrado en la villa de Aguilafuente, de señorío capitular, rompiendo la puerta y tomando todo el pan que había en ella, y además haber roto también la carta que el provisor había mandado para que fuese leída al dicho Lope ${ }^{120}$.

Respecto a los conflictos, no queda sino hablar de los que surgían entre los prelados y sus propios vasallos. En 1215 Enrique I falló en el pleito que enfrentaba al obispo con sus vasallos de Mojados "super fonsadera et pedido et pecta quod ab eis idem episcopus exigebat", dando la razón al prelado $^{121}$. En 1220 el cabildo de Segovia llegaba a un acuerdo con los concejos de sus villas de Pelayos del Arroyo y Sotosalbos sobre "multas controvertias habitas inter nos", especialmente acerca de los derechos que el cabildo debía percibir por diferentes conceptos ${ }^{122}$. En 1294 Sancho IV confirmaba su carta del año anterior por la que ordenaba al concejo de Mojados que no pusiera alcaldes ni jueces ni escribanos ni otros oficiales,

\footnotetext{
${ }^{117} 1293$, septiembre, 21. Burgos. ACS, 9-8-bis. Reg. SANZ, doc. 200.

${ }^{118} 1405$, julio, 29. Segovia. Ed. SEPÚlvedA, doc. 98, y reg. RiazA, doc. 27.

${ }^{119} 1445$, marzo, 7. Sotosalbos. Cit. Colmenares, II, pp. 23-24, nota 8.

${ }^{120} 1506$, agosto, 1. Segovia. ACS, G-53.

121 1215, noviembre, 20. Valladolid. Ed. VILLAR, doc. 105, y cit. Colmenares, I, p. 349.

${ }^{122} 1220$, enero. ACS, 4-3. De. VILLAR, doc. 112.
} 
pues ésta era prerrogativa de los obispos de Segovia, sus señores ${ }^{123}$. En alguna ocasión el obispo aparece participando de un modo más o menos directo en los problemas internos de sus villas de señorío. Así, en 1427 el prelado segoviano don Juan autorizaba a los pecheros de su villa de Turégano a vender ciertos solares en la plaza del mercado, a petición de éstos, pues necesitaban dinero para continuar el pleito que mantenían con los hijosdalgos de la villa, y daba validez a otras ventas similares ya realizadas $^{124}$.

Una forma muy eficaz de regular de un modo global la relación entre el señor y su villa consistía en la concesión de un fuero. De este modo, Luguillas fue dotada de fuero por el obispo Raimundo de Losana en $1255^{125}$ y Mojados recibió el suyo del obispo don Blasco en 1293, siendo ratificado al año siguiente por Sancho IV ${ }^{126}$.

Como en el resto de los señoríos, los vasallos pertenecientes a la dignidad episcopal estaban sujetos al pago de tributos de reconocimiento, relacionados con el vínculo de vasallaje y cuyo valor no era sólo económico sino también simbólico, y de otros derivados del monopolio señorial sobre determinados bienes como las aguas, los bosques o los molinos, al tiempo que resulta muy posible que mantuvieran también algún tipo de prestación personal. El caso de Turégano, la villa principal del señorío episcopal, puede servir como ejemplo para acercarse a la dinámica económica de los demás lugares pertenecientes a este señorío ${ }^{127}$.

El cobro de los diezmos en esta villa suponía la renta de mayor importancia para los obispos, situándose en segundo lugar lo obtenido por los bienes sobre los que mantenía el dominio eminente pero de los que había cedido el dominio útil a los campesinos para su explotación. Se trataba de posesiones rústicas y urbanas entre las que se pueden destacar tierras de "pan llevar", viñas, huertas o casas, y que incluía otras ciertamente atípicas como un pozo de nieve en Mojados. A estas rentas había que sumar las derivadas de los derechos jurisdiccionales a través, por ejemplo, del ejercicio

\footnotetext{
${ }^{123} 1294$, enero, 28. Palencia. ACS, B-302-bis, fols. $12 \mathrm{v}-13 \mathrm{r}$.

${ }^{124} 1427$, febrero, 17. Valencia. ADS, legajo 124.

${ }^{125} 1255$, noviembre, 22. Segovia. ACS, B-329, fols. $26 \mathrm{r}-26$ v. Ed. VILLAR, doc. 158 , y cit. Colmenares, I, p.398.

1261294, abril, 19. Valladolid. ACS, 9-9-bis. Ed. VILLAR, doc. 229, y cit. ColmEnARES, I, p. 455 , nota 42.

${ }^{127}$ Sigo aquí a M. Barrio Gozalo, op. cit., pp. 205-210.
} 
de la justicia, cuyos ingresos por multas, las llamadas "penas de cámara", podían llegar a ser relativamente importantes. Además de éstas, había otras tasas relacionadas con la administración, como el cánon que pagaban los dos escribanos de la villa, el de número y el del ayuntamiento, por el arrendamiento de dicho oficio. Como rentas propiamente señoriales los obispos recibían la martiniega, el portazgo y algún otro tributo como el conocido bajo la denominación explícita de "feudo", y que en Mojados obligaba a cada vecino pechero a pagar anualmente media fanega de cebada y una cántara de vino. A este último grupo de rentas habría que sumar las obtenidas por el monopolio sobre determinados bienes como los molinos, o sobre determinados recursos naturales como los pastos, los bosques, y su aprovechamiento en madera, leña o caza, o las aguas y sus derechos de pesca o riego.

\section{Siglo XVI. DESMEMBRACIÓN DEL SEÑORÍO}

Un fenómeno que aparece documentalmente en el siglo XVI, pero que debía existir desde el momento mismo en que se creó el señorío temporal de los obispos de Segovia, era el de las tomas de posesión "sede episcopali vacante" de las villas de señorío episcopal. Cuando un prelado abandonaba su sede, bien fuera por muerte o promoción, era el cabildo de la catedral el encargado de custodiar los bienes de la mitra hasta que el nuevo obispo tomara posesión. En estos casos el deán comisionaba a varios canónigos, generalmente dos, para que tomaran posesión de las villas, las fortalezas donde hubiera éstas y el resto de "sus tierras e jurisdiçiones". También debían hacerse cargo provisionalmente de los pleitos que surgieran y resolver los que estaban pendientes, ratificar a los alcaldes "entre tanto que se provee otra cosa", y reunir al concejo para que éste "conforme a la costumbre" eligiera a los oficiales. Por último, se pregonaba juicio de residencia por treinta días "de todos los que an tenido cargo y administraçión de justicia". Una vez realizadas todas estas actuaciones en el conjunto de las villas de señorío debían volver a Turégano, "la cabeza y lugar más principal", mandar un informe de las gestiones realizadas y entre tanto 
estarse allí ${ }^{128}$. Toda esta situación de provisionalidad cesaba cuando el nuevo titular de la diócesis tomaba posesión de su cargo y pasaba a administrar directamente los bienes de la mitra, entre los que, por supuesto, se encontraban sus villas de señorío.

La desmembración del señorío eclesiástico en la diócesis de Segovia se inició en 1536 con la venta por parte del cabildo de sus tres villas de señorío, Aguilafuente, Pelayos del Arroyo y Sotosalbos, a Pedro de Zúñiga, duque de Béjar, por treinta y dos mil ducados de oro "que montan doze quentos de maravedíes"129. Para Miguel Santamaría la explicación de esta venta hay que buscarla "en la crisis que el señorío, como forma de explotación detentada por la aristocracia feudal, experimentó desde el siglo XIV y especialmente en el XV, caracterizada por la bajada general de las rentas"130. Desde este punto de vista, la venta no era sino la consecuencia de un proceso iniciado cincuenta años antes, cuando se planteó por primera vez la liquidación de los lugares de señorío, y que pretendía obtener con ello, en palabras de los capitulares, otras rentas de mayor utilidad.

A pesar de la importancia que la búsqueda de bienes más rentables tuviera en la venta por el cabildo de sus tres villas de señorío, no conviene dejar de lado otro factor que también influyó en esta decisión. El traslado de la catedral de Segovia era un asunto que se había planteado ya muy seriamente con Enrique IV, pero las negativas del cabildo habían terminado paralizando el proyecto. Una vez restablecido el orden tras la guerra de las Comunidades, Carlos I retomó la vieja idea del traslado de la catedral, que esta vez se llevó a cabo pues todas las circunstancias favorecían el mismo y el cabildo no estaba en condiciones de oponerse, esta vez, a los deseos del monarca. Pero el patrocinio real no fue acompañado de una dotación económica adecuada, muy posiblemente en castigo por el decidido apoyo segoviano a la causa comunera, por lo que el cabildo se vio en la necesidad de utilizar todos los recursos posibles para sacar adelante una obra de tal magnitud. En este contexto de búsqueda de liquidez económica se produjo la venta por el cabildo de sus villas de señorío. De hecho, la institución capitular había comenzado las gestiones para la venta dos años. antes, en

\footnotetext{
${ }^{128} \mathrm{ACS}, \mathrm{H}-128$. Este legajo contiene varias cartas de poder de las que se han extractado estos datos, y unas instrucciones de 1543 publicadas estas últimas por V. BORREGUERO VIRSEDA, op. cit., pp. 380-383.

${ }^{129} 1536$, octubre, 22. Segovia. ADS, legajo 121.

${ }^{130}$ M. Santamaría Lancho, op. cit., p. 453.
} 
1534, pero de un modo tan discreto que ni siquiera el obispo sabía nada de ello. Las circunstancias de la venta fueron amargamente criticadas por Diego de Rivera, el prelado segoviano, en una carta remitida al cabildo seis días antes de que se produjera la enajenación, cuando, de hecho, nada se podía hacer para impedirla. Don Diego les recriminaba lo apresurado y poco reflexivo de la venta: "ya creo que conoceis que en todas las cosas se halla haz y envés y lo que agora os parece bueno después de hecho por ventura os parecería no tal y sería entonces de poco fruto el arrepentimiento". También se quejaba, como ya se ha apuntado, de "que después que ésto está podrido en vuestros pechos y a cabo de dos annos, que agora sé que se trata". Por último, consideraba que la venta rompía con las obligaciones que los capitulares tenían "con Dios y con el mundo y con vuestras conciencias y con lo que sois obligados"131. Finalmente la enajenación se produjo y algún tiempo después el cabildo intentó, sin ningún éxito, "anular esta venta y recuperar su señorío sobre estas tres villas" ${ }^{132}$.

Gregorio XIII mediante una bula de 6 de abril de 1574 concedió a Felipe II la potestad de enajenar, aun sin el consentimiento de los prelados pero mediante una equitativa recompensa, cualquier villa o lugar perteneciente a la Iglesia española ${ }^{133}$. El 30 de diciembre de 1574 este monarca iniciaba la desmembración del señorío temporal de los obispos de Segovia incorporando a la "corona y patrimonio real la villa de Mejorada con sus vasallos, términos y jurisdiçión cebil y criminal alta y baxa, mero mixto imperio con las rrentas jurisdicionales della que son las penas de cámara y de sangre, legales y arbitrarias y la martiniega y escrivanías públicas" y del concejo y otras quales quier rrentas, pechos y derechos anexas y pertenesçientes a la dicha jurisdición, señorío y vasallaje della y con el derecho de elegir alcaldes hordinarios y de la hermandad, rregidores, alguaçiles y otros offiçiales que se suelen y acostumbran nombrar para el uso y exercicio de la dicha jurisdiçión". A cambio entregaba mil seiscientos diez maravedíes anuales de juro sobre las alcabalas de Segovia ${ }^{134}$. En 1579 cuatro pueblos más fueron incorporados por la corona. El 31 de mayo Belmonte de Tajo por catorce mil setecientos veintiún maravedíes anuales sobre las alcabalas

\footnotetext{
${ }^{131} 1536$, octubre, 16. Valladolid. ACS, G-66.

${ }^{132} \mathrm{~A}$. de Ceballos-Escalera y Gila, op. cit., p. 64.

${ }^{133}$ M. BARRIO GoZALO, op. cit., p. 202.

${ }^{134} \mathrm{ADS}$, legajo 118
} 
de Segovia ${ }^{135}$; el 30 de julio Navares de las Cuevas por setecientos cinco maravedíes anuales sobre las alcabalas de Segovia ${ }^{136}$; el 10 de septiembre Veganzones por dos mil cuatrocientos cincuenta maravedíes anuales sobre las alcabalas de Segovia ${ }^{137}$; y el 13 de octubre Laguna de Contreras por tres mil setecientos dos maravedíes anuales sobre las alcabalas de Segovia $^{138}$. Entre 1579 y 1581 la corona enajenó también las villas de Caballar y Fuentepelayo ${ }^{139}$. El 2 de diciembre de 1580 Felipe II encargó una valoración de las rentas de Turégano, lo que constituía el paso previo para su incorporación a la corona. El obispo se opuso inmediatamente, argumentando "el perjuicio que en la venta de ella había la mitra ... por haber sido y ser la cabeza y lugar más principal que había tenido y tenía la cámara de los obispos", además razonaba que "habían vendido a Su Magestad seis villas que tenían que fueron las de Fuentepelayo, Laguna de Contreras, Navares de las Cuevas, Veganzones, la de Caballar y la de Pozuelo, con las que se habían dado más de dos mil vasallos ${ }^{140}$. Finalmente el monarca desestimó la enajenación y Turégano permaneció bajo la jurisdicción episcopal. Así pues, tras las incorporaciones por Felipe II a la corona de Belmonte de Tajo, Caballar, Fuentepelayo, Laguna de Contreras, Mejorada del Campo, Navares de las Cuevas y Veganzones, y la salida de la jurisdicción episcopal, aunque en momentos y circunstancias desconocidas de Bobadilla, Gerindote y Luguillas, los obispos de Segovia perdían todos sus lugares de señorío al sur de la sierra, y al norte conservaban tan solo dos de ellos, Turégano y Mojados, situados en su propia diócesis".

\section{TurÉgano y Mojados. Pervivencias SeÑoriales}

Durante los dos siglos que Turégano y Mojados constituirían la única posesión señorial de los obispos de Segovia, los lazos entre éstos y sus

\footnotetext{
${ }^{135} \mathrm{ADS}$, legajo 118.

${ }^{136}$ ADS, legajo 121.

${ }^{137} \mathrm{ADS}$, legajo 121.

${ }^{138} \mathrm{ADS}$, legajo 121.

${ }^{139}$ A. García SANZ, op. cit., p. 339.

${ }^{140} \mathrm{ADS}$, legajo 118. Ambas noticias, la de la valoración de las rentas de Turégano y la respuesta del obispo, se encuentran en unos papeles que recogen diversas noticias sobre el señorío de los obispos en Turégano.
} 
vasallos se irían adecuando progresivamente a las nuevas circunstancias. Aunque en un plano teórico los prelados mantenían todos sus derechos, éstos habían sido matizados por el paso del tiempo. En el plano económico, por ejemplo, los ingresos procedentes del dominio señorial eran menores que los que se derivaban del dominio eminente ${ }^{141}$. Las fórmulas con que los vasallos se referían a su señor como "nuestro protector" o "nuestro dueño", y a ellos mismos como "sus fieles vasallos y rendidos súbditos", respondían más a una lógica muestra de respeto que al reflejo de una situación real.

Uno de los aspectos donde mejor se puede apreciar el mantenimiento por parte del obispo de sus prerrogativas tradicionales, pero con importantes modificaciones a favor de sus vasallos, era el del nombramiento de cargos concejiles, con una mecánica establecida ya desde mediados del siglo $\mathrm{XVI}^{142}$.

Anualmente se habían de elegir dos alcaldes, uno por el estado noble y otro por el general, dos regidores, también uno por el estado noble y otro por el general, y un alguacil. Todos los años en los últimos días de noviembre o primeros de diciembre, un cuerpo de electores formado por la justicia, regimiento y alguacil mayor que eran al presente y los del año anterior realizaban una votación de la que resultaban dos candidatos por cargo. Si para alguno de los puestos había varios candidatos con el mismo número de votos, se efectuaba un sorteo entre ellos para designar al que ocupara la plaza. Estos candidatos debían tener lo que denominaban "los huecos suficientes", esto es, no tener parentesco alguno con los electores, deudas pendientes ni tacha legal. Una vez realizados estos trámites el concejo enviaba al obispo la relación de candidatos y la certificación de que cumplían los requisitos establecidos. Desde este momento y hasta que el obispo tomaba una decisión se abría un plazo de alegaciones que podían deberse a varias causas. En 1804 los cargos de Turégano informaron al prelado de la muerte de Alfonso Álvarez, primer candidato para regidor del estado general, rogando que eligiera al situado en segundo lugar "para que pueda jurar con los demás individuos el día de año nuevo según costumbre" ${ }^{143}$.

${ }^{141}$ M. BARRIO GoZALO, op. cit., p. 210.

${ }^{142} \mathrm{ADS}$, legajo 119 ( 2 y 3 ). Contiene las propuestas para cargos en Turégano y Mojados desde mediados del siglo XVII a 1804. V. BORREGUERO VIRSEDA, op. cit., pp. 387-388, ofrece un testimonio de 1574 sobre la elección de cargos cuya mecánica era ya muy similar a la que se utilizaría en los siglos posteriores.

${ }^{143} 1804$, diciembre, 30. Turégano. ADS, legajo 119-3. 
En 1802 el escribano del número de Mojados certificaba que la elección para alcalde del estado noble de Francisco Martínez no era válida por razón de parentesco y había que realizar una nueva propuesta entre personas "que no padezcan escepción legal"144. Todos los vecinos varones y mayores de edad de estas villas eran susceptibles de ocupar alguno de los puestos concejiles y aunque no podían evitar su candidatura sí tenían la posibilidad de alegar al obispo antes de que éste tomara una decisión. Así, en 1767 se pedía al prelado que no eligiera a Manuel González como alcalde del estado general "pues tiene 70 años, está muy achacošo y nunca se a escusado de servir los empleos de la república hasta aora que no puede"145. En 1787 se solicitaba del obispo que no eligiera a Juan Antonio de Miguel como alguacil "porque no tiene para su manutención, la de su mujer, que hace mucho tiempo se halla enferma, y la de su familia más arbitrios que el jornal diario el que, si se le nombrase por tal alguacil mayor, le faltaría muchos días por ser empleo mui gravoso y se verá, y su familia, sin tener con qué alimentarse"146. En otros casos, buscando "las luces necesarias para la mejor elección", el obispo pedía informes sobre algunos de los candidatos o éstos le eran enviados espontaneamente por personas de su confianza. Una vez que el prelado había tomado una decisión la enviaba al concejo para su conocimiento. La toma de posesión de los nuevos cargos se realizaba el primero de enero. En el caso de Turégano, donde los obispos pasaban muchas navidades, eran ellos mismos quienes tomaban juramento a los electos y les entregaban los oficios. En Mojados esto se hacía por medio de delegados de la dignidad episcopal, y en 1767 justicia y regimiento de la villa rogaban al prelado que les mandase una persona para recibir el juramento de los nuevos cargos pues los dos años anteriores no había ido nadie a hacerlo ${ }^{147}$.

El 25 de febrero de 1805 Carlos IV promulgaba una Real Cédula "por la que es servido de mandar que los señoríos temporales y jurisdiccionales que poseen las mitras y demás dignidades eclesiásticas de estos reinos se incorporen a la Corona"148. El 7 de marzo de ese año era enviada al

\footnotetext{
${ }^{144} 1802$, mayo, 30. Mojados. ADS, legajo 119-3.

${ }^{145} 1767$, diciembre, 17. Mojados. ADS, legajo 119-3.

${ }^{146} 1787$, diciembre, 25. Turégano. ADS, legajo 119-3.

${ }^{147} 1767$, diciembre, 17. Mojados. ADS, legajo 119-3.

${ }^{148} \mathrm{ADS}$, legajo 118.
} 
obispo de Segovia en su calidad de señor de vasallos. Los últimos días de 1806 recibía el prelado segoviano otra Real Cédula de 12 de diciembre de ese mismo año en la que se especificaba ya "la forma en que se ha de executar la incorporación a la Corona de los señoríos temporales y jurisdicciones que poseen las mitras y otras dignidades eclesiásticas de España, resuelta por otra de 25 de febrero próximo pasado"149. De hecho, las últimas propuestas de cargos concejiles que se conservan tanto para Turégano como para Mojados son las realizadas en 1804 para cubrir los puestos del año siguiente, lo que permite suponer que para 1805 la mencionada Real Cédula de 25 de febrero había surtido efecto y el nombramiento de alcaldes, regidores y alguacil no dependía ya del obispo ${ }^{150}$. Sin embargo, es posible que diversas circunstancias paralizaran, al menos en parte, el proceso, pues sólo así se explica que el 2 de mayo de 1815 el canónigo Manuel de Alvaro Benito tomara posesión, como se había hecho desde hacía siglos, de la villa y fortaleza de Turégano en nombre del obispo Isidoro Pérez de Celis, ya "que a dicho Señor Ilustrísimo y a su dignidad episcopal le corresponde el señorío temporal y espiritual de esta villa"151. Una carta de 1819 nos permite suponer que el proceso de separación de Turégano y Mojados de la autoridad episcopal no se produjo precisamente hasta 1815. Eugenio González, vecino de Mojados, solicitaba al obispo de Segovia que le certificase que ya no pertenecían a la dignidad episcopal las escribanías del número y ayuntamiento de esa villa, "bajo el supuesto de que haviendo correspondido antes a Vuestra Señoría Ilustrísima a virtud de su señorío temporal de esta villa, corresponde hoy a Su Magestad (que Dios guarde) a consecuencia de la orden de ochocientos quince"152.

En todo caso, y aunque la autoridad del obispo de Segovia sobre Turégano y Mojados se extendiera, como parece, hasta 1815, la Real Cédula de 1805 había supuesto de hecho la sentencia definitiva sobre las posesiones señoriales de los prelados segovianos, una institución que durante siete siglos permitió a los obispos segovianos ser no sólo pastores de fieles, sino también señores de vasallos.

\footnotetext{
${ }^{149} \mathrm{ADS}$, legajo 118

${ }^{150} 1804$, noviembre, 29. Turégano, y 1804, diciembre, 18. Mojados. ADS, legajo 119-3.

${ }^{151} \mathrm{ADS}$, legajo 118.

${ }^{152} 1819$, marzo, 2. Mojados. ADS, legajo 119-3.
} 


\section{RELACIÓN DE LOS LUGARES DE SEÑORÍO EPISCOPAL Y CAPITULAR ${ }^{153}$}

\begin{tabular}{lrll} 
& A & \multicolumn{1}{c}{ B } & \multicolumn{1}{c}{ C } \\
AGUILAFUENTE & 1124 & 1536 & Segovia \\
ALCAZARÉN & 1140 & 1181 & Valladolid \\
ALDOVEA (Castillo de) & 1150 & 1154 & Madrid \\
BELMONTE DE TAJO & 1149 & 1579 & Madrid \\
Bobadilla & 1124 & XVI & \\
CABALLAR & 1123 & $1579-81$ & Segovia \\
CALATALIFA (Castillo de) & 1136 & 1161 & Madrid \\
COLLADO HERMOSO & 1123 & 1139 & Segovia \\
Fregacedos & 1144 & XIII & Madrid \\
FRESNO DE CANTESPINO & 1204 & 1214 & Segovia \\
FUENTEPELAYO & 1181 & $1579-81$ & Segovia \\
GERINDOTE & 1136 & XVI & Toledo \\
ILLESCAS & & 1124 & Toledo \\
LAGUNA DE CONTRERAS & $1130^{154}$ & 1579 & Segovia \\
Luguillas & $1209^{155}$ & XVI & Valladolid \\
MEJORADA DEL CAMPO & $1247^{156}$ & 1574 & Madrid \\
MOJADOS & 1181 & 1805 & Valladolid \\
Morcheles & 1137 & XIII & \\
& & & \\
\hline
\end{tabular}

\footnotetext{
${ }^{153}$ Explicación de la tabla:

-A. Año de incorporación al señorío; B. Año de salida del señorío; C. Provincia a la que pertenece.

-Se han escrito en mayúscula los pueblos que existen actualmente y en minúscula los que han desaparecido.

-No se incluyen Arcicóllar (1146) y Salzedón (1137) por ser donaciones personales.

-Aguilafuente desde 1216 y Sotosalbos desde 1247 habían pasado del señorío episcopal al capitular. Pelayos del Arroyo desde 1220 aparece integrado directamente en el señorío capitular.

${ }^{154}$ Es la primera referencia documental.

${ }^{155}$ Es la primera referencia documental.

${ }^{156}$ Es la primera referencia documental.
} 


$\begin{array}{llll}\text { NAVARES DE LAS CUEVAS } & 1158 & 1579 & \text { Segovia } \\ \text { PELAYOS DEL ARROYO } & 1220^{157} & 1536 & \text { Segovia } \\ \text { Receixada } & 1150 & \text { XIII } & \text { Madrid } \\ \text { RIAZA } & 1139 & 1430 & \text { Segovia } \\ \text { SOTOSALBOS } & 1122^{158} & 1536 & \text { Segovia } \\ \text { TURÉGANO } & 1123 & 1805 & \text { Segovia } \\ \text { VEGANZONES } & 1405^{159} & 1579 & \text { Segovia }\end{array}$

\section{RÉSUMÉ}

Ce travail veut offrir une vue générale du seigneuriage des évêques de Ségovie à partir de sa formation, au début du XIIème siècle jusqu'à sa liquidation au XIXème siècle, en s'appuyant spécialement sur son développement pendant l'étape médiévale.

Si les seigneuriages écclésiastiques en général sont peu connus, le cas de Ségovie est trés significatif de ce côté-là. Il existe uniquement quelques notes sur ce thème qui prouvent la difficulté à accéder aux documents originaux. La mise en catalogues et l'ouverture des archives écclésiastiques en général et ceux de Ségovie en particulier, et la publication de sources et de collections de documents ont permis de connaître maintenant ce phénomème seigneurial, dynamique et complexe pendant son existence de sept siècles.

\section{SUMMARY}

This report offers a general view of the lordship of the bishop of Segovia, from its foundation at the beginnings of the XII century, till its end in the XIX century, emphasizing its development during the Middle Ages.

Little is known about the ecclesiastical lordships and the Segovian case is specially interesting. The existence only of few pieces of information on this subject demonstrate the difficulty of access to the original documents.

The cataloguing and opening of ecclesiastical archives in general, and those of Segovia in particular, and the publication of documental sources and collections have now allowed us to get to know this phenomenon, dynamic and complex, throughout seven centuries of existence.

\footnotetext{
${ }^{157}$ Es la primera referencia documental.

${ }^{158}$ Es la primera referencia documental.

${ }^{159}$ Es la primera referencia documental.
} 